\title{
Development of rainfall recharge model for natural groundwater recharge estimation in Godagari Upazila of Rajshahi district, Bangladesh
}

\author{
Md. Nurul Islam ${ }^{1, ~ *}$, Anupam Chowdhury ${ }^{1}$, Kazi Moinul Islam², Mohammed Ziaur Rahaman ${ }^{2}$ \\ ${ }^{1}$ Department of Civil Engineering, Rajshahi University of Engineering \& Technology, Rajshahi, Bangladesh \\ ${ }^{2}$ Department of Civil Engineering, Southern University Bangladesh, Chittagong, Bangladesh
}

\section{Email address:}

nurulislam.ce@gmail.com (Md. N. Islam), anupam.19ce@gmail.com (A. Chowdhury), engrruet02@gmail.com (K. M. Islam), ziaruetce1@yahoo.com (M. Z. Rahaman)

\section{To cite this article:}

Md. Nurul Islam, Anupam Chowdhury, Kazi Moinul Islam, Mohammed Ziaur Rahaman. Development of Rainfall Recharge Model for Natural Groundwater Recharge Estimation in Godagari Upazila of Rajshahi District, Bangladesh. American Journal of Civil Engineering. Vol. 2, No. 2, 2014, pp. 48-52. doi: 10.11648/j.ajce.20140202.16

\begin{abstract}
Estimation and forecast of groundwater recharge and capacity of aquifer are essential issues in effective groundwater resource management in Bangladesh. Godagari Upazilla is located in High Barind Tract situated in the northwestern part of Bangladesh. A typical dry climate with comparatively high temperature prevails in this Barind area. It is particularly significant in regions with large demands for groundwater supplies to meet irrigation needs, where such resources are the key to economic growth. However, the rate of aquifer recharge is one of the most complicated factors to assess in the evaluation of groundwater resources. Assessment of recharge, by whatever method, is normally subject to large uncertainties and errors. In this paper, an attempt has been taken to develop a rainfall recharge model by non-linear regression technique to determine groundwater recharge using only annual rainfall data in Godagari Upazilla based upon groundwater balance study carried out for a number of years. It was also proven that the developed model provided an accurate estimation for similar projects.
\end{abstract}

Keywords: Ground Water, Rainfall, Recharge, Water Balance

\section{Introduction}

Groundwater is located beneath the ground surface of the earth as a dynamic system. It occurs and moves with the control of various parameters, which are studied in different fields of sciences such as hydrogeology, hydrology and climatology [1]. Among the parameters controlling situation and groundwater fluctuation, recharge is an important factor need to be assessed very carefully [2].

The amount of water that will ultimately arrive at the water table is defined as natural ground water recharge. The amount of this recharge depends upon the rate and duration of rainfall, the subsequent conditions at the upper boundary, the antecedent soil moisture conditions, the water table depth and the soil type. Recharge is taking place in little and significant quantity for spatially and temporally is subjective by parameters such as meteorology, soil characteristics, earth surface cover, slope and deepness of groundwater level $[3,4,5]$. The assessment of groundwater recharge from precipitation is a major part of hydrology and hydrogeology [6]. While precipitation is the most significant source of groundwater recharge, the accuracy of currently attainable techniques for measuring recharge is not completely acceptable [5,7]. Moreover, there is no practice for direct measurement of recharge due to the lack of universal typical methods [8].

To estimate the groundwater recharge, hydro-geologists have used physical, chemical, and/or numerical methods [9]. Chandra (1979) specified that the following methods can be prevalently applied to estimate the natural groundwater recharge: soil water balance method; zero flux plane method; one-dimensional soil water flow model; inverse modeling technique; ground water level fluctuation method; hybrid water fluctuation method; ground water balance method; isotope and solute profile techniques [10]. A different categorization for estimation of groundwater 
recharge presented by Kumar (2000) classified the methods of assessment of groundwater recharge into four groups: empirical methods; groundwater resource estimation; groundwater balance approach and soil moisture data based methods [11].

\section{Materials and Methods}

\subsection{Study Area Description}

Godagari is the largest Upazila of Rajshahi district with an area of 472.13 sq. $\mathrm{km}$ are bounded by Nawabganj sadar, Tanore Paba Upazilas, West Bengal of India "Fig. 1". The Padma River is passing through the site. From the geological point of view, the study area mainly consists of stiff clay red color which is significant in comparison with other part of the country. Vegetation cover consists of trees, shrubs, grass and low bush. The study area is situated in Barind tract, which is the Northern part of Bangladesh. The Rajshahi Barind tract is situated in between 24 degree 23 minute to 25 degree 15 minute north latitude and 88 degree 2 minute to 88 degree 57 minute east longitude.

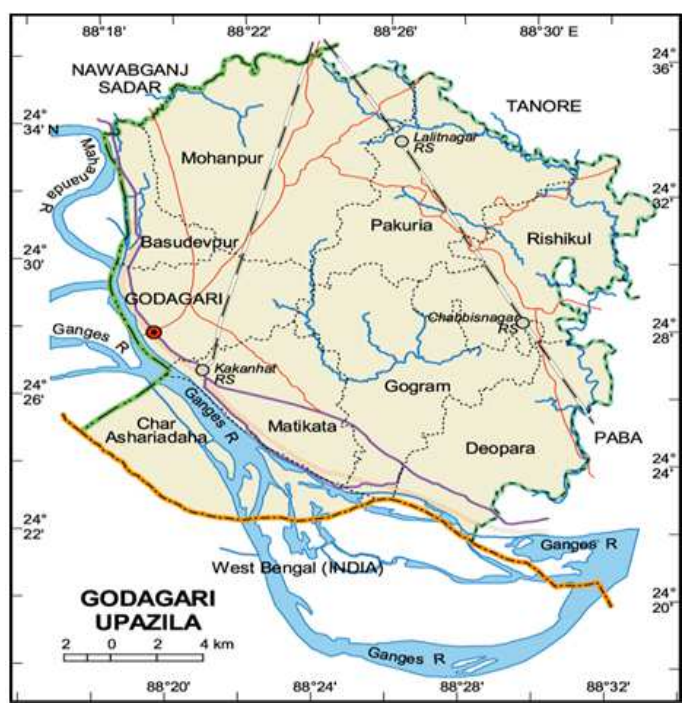

Figure 1. Location of study area.

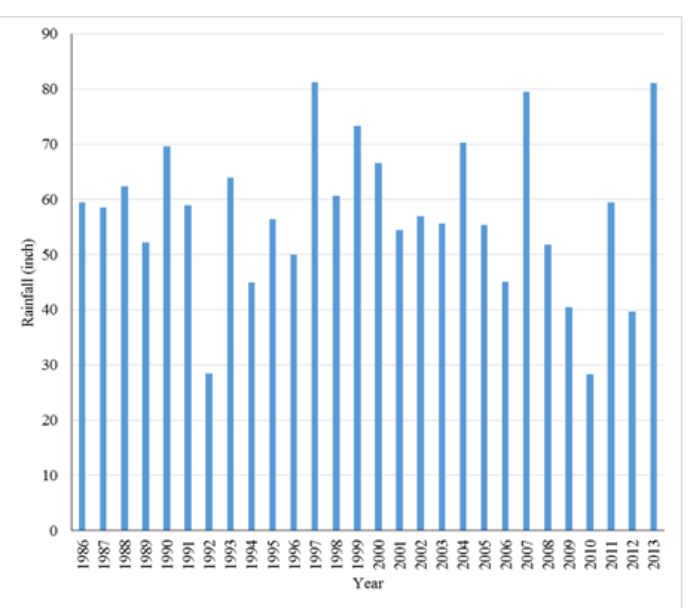

Figure 2. Annual rainfall between 1986 and 2013 (inch per year).
The climate of the projected area is more and less the average for the country as a whole characterized by the two distinct seasons such as the wet season from June to September and the dry season during rest of the year. The annual rainfall varies from 1500 to $2000 \mathrm{~mm}$. The annual pan evaporation for the area is around $720 \mathrm{~cm}$ [13]. "Fig. 2" illustrates an annual rainfall in the region between years 1986 and 2013.

The average temperature of the study area is varies between 8 to $44^{\circ} \mathrm{C}$. January and February are the coolest month when temperature falls below $8^{\circ} \mathrm{C}$. Summer starts abruptly in March and is described by a hot north westerly wind a quick increase in mean daily relative humidity from 60 to $85 \%$. Temperature is high as $43^{\circ} \mathrm{C}$ is experienced for some time during summer season [13].

About $36.36 \%$ peoples are dependent on agriculture in Godagari Upazila. Total cultivable land is 35750.71 hectares and the fallow land is 218.74 hectares in study area [12]. In the study area groundwater is the main source of irrigation. For proper irrigation system the prime needs to know about groundwater storage. From this point of view the site was selected as study area for groundwater recharge assessment.

\subsection{Water Balance Method}

Rainfall is the vital resource of ground water recharge in the country. The most commonly used methods for estimation of ground water recharge in Bangladesh include empirical relationships and water balance method. Water balance methods have been widely used to estimates of water resources and the influence of human's accomplishments on the hydrologic cycle. Depending upon the water balance approach, it is possible to create a quantitative evaluation of water resources and its self-motivated behavior under the impact of human's activities. The study of water balance is defined as the efficient behavior of data on the supply and use of water surrounded by a topographical area for a definite period. With water balance approach, it is possible to estimate quantitatively individual impact of sources of water in the system, over different time phases, and to establish the degree of variation in water regime due to fluctuations in components of the system.

The basic concept of water balance is:

Inflow of the system - Outflow from the system $=$ Change in storage of the system (Over a period of time).

Considering the various inflow and outflow components, the ground water balance equation for a time period, $\Delta \mathrm{t}$ is given as follows

$$
\left(\mathrm{P}+\mathrm{F}_{\mathrm{i}}\right)-\left(\mathrm{E}_{\mathrm{t}}+\mathrm{S}_{\mathrm{m}}+\mathrm{T}_{\mathrm{p}}+\mathrm{C}_{\mathrm{u}}+\mathrm{R}_{\mathrm{o}}\right)=\Delta \mathrm{S}
$$

Where,

$\mathrm{P}=$ Precipitation.

$\mathrm{F}_{\mathrm{i}}=$ Field Irrigation.

$\mathrm{E}_{\mathrm{t}}=$ Evapotranspiration. 
$\mathrm{S}_{\mathrm{m}}=$ Soil Moisture.

$\mathrm{T}_{\mathrm{p}}=$ Draft from groundwater by wells.

$\mathrm{C}_{\mathrm{u}}=$ Consumptive use of water for crop growing.

$\mathrm{R}_{\mathrm{o}}=$ Surface Runoff.

$\Delta \mathrm{S}=$ Change in groundwater level.

"Equation (1) is the general water balance equation for an unconfined aquifer in study area". All the components of the water balance equation are computed using independent approaches where possible [14, 15, 16].

The difficulties of the computation of the water balance tend to increase with the increase in area. This is due to an associated increase in the methodological effort of precisely computing the various vital water balance components. To apply equation (1) properly, it is important that both the area and the period for which the balance is evaluated, be carefully selected.

A pre-requisite for effective application of this method is very extensive and precise hydrological and meteorological data. The water balance method is valid for the area because former yields assessment of recharge coefficient and the advanced controls to the degree of accuracy with which the components of water balance equation have been estimated.

The steps to be followed to determine the change in storage of groundwater by water balance study are:

$>$ Required data was collected from Bangladesh Meteorological Department (BMD) and Upazila agriculture office.

$>$ The total field irrigation was calculated from both surface and groundwater sources.

$>$ Evapotranspiration was calculated using the pan evaporation data.

$>$ Soil moisture was calculated using moisture content before and after the applying water over the ground.

$>$ Draft from groundwater was calculated using discharge capacity, governing area and average running hours in a year of various wells.

$>$ Consumptive use for crop growth (building tissues, etc.) was calculated using Blaney-Criddle equation.

$>$ Surface runoff was calculated using runoff coefficient.

Substitution was made for above parameters estimations in the water balance equation and thus groundwater recharge and recharge coefficient (recharge/rainfall ratio) was calculated.

\section{Model Analysis Approach and Result}

\subsection{Estimation of Groundwater Recharge}

A Portion of the precipitation that falls on the ground is infiltrated into the soil. This infiltrated water is applied partly in filling the soil moisture insufficiency and a quantity of it is percolated down to attain water table. This water accomplishment the water table is known as the recharge from rainfall to the aquifer. Recharge due to rainfall depends on several hydro-meteorological and topographic factors, soil characteristics and depth to water table.

The water balance method for the study area was carried out yearly from 1986 to 2013. All components of the water balance equation, except rainfall recharge were estimated using the relevant hydrological and meteorological information. The rainfall recharge of the study period was calculated by substituting these estimates in the water balance equation.

\subsection{Estimation of Recharge Coefficient}

The amount of recharge coefficient is defined as the ratio of recharge to rainfall and expressed in percentage [17]. It was observed that as the rainfall increases the amount of recharge also increases but the increase is not linearly proportional. The recharge coefficient was found to vary between 0.029 to 0.105 for the study area. Keeping in view the large study area (472.13 sq.km.) and the total amount of water involved, this amount of unaccounted water seems to be quite reasonable and within limits. Table 1 presents the rainfall recharge of the study period and the corresponding recharge coefficients.

Table 1. Estimation of Ground Water Recharge by Water Balance Method.

\begin{tabular}{cccc}
\hline Year & $\begin{array}{c}\text { Total Rainfall } \\
\text { (in.) }\end{array}$ & $\begin{array}{c}\text { Ground Water } \\
\text { Recharge (in.) }\end{array}$ & $\begin{array}{c}\text { Recharge } \\
\text { co-efficient }\end{array}$ \\
\hline 1986 & 59.45 & 5.84 & 0.098 \\
1987 & 58.54 & 5.87 & 0.100 \\
1988 & 62.36 & 6.41 & 0.103 \\
1989 & 52.17 & 4.92 & 0.094 \\
1990 & 69.57 & 6.81 & 0.098 \\
1991 & 58.98 & 6.15 & 0.104 \\
1992 & 28.50 & 0.83 & 0.029 \\
1993 & 63.90 & 6.49 & 0.102 \\
1994 & 44.96 & 4.33 & 0.096 \\
1995 & 56.38 & 5.62 & 0.100 \\
1996 & 49.96 & 4.74 & 0.095 \\
1997 & 81.18 & 8.04 & 0.099 \\
1998 & 60.63 & 6.28 & 0.104 \\
1999 & 73.31 & 7.34 & 0.100 \\
2000 & 66.54 & 6.98 & 0.105 \\
2001 & 54.41 & 5.21 & 0.096 \\
2002 & 56.89 & 5.73 & 0.101 \\
2003 & 55.59 & 5.65 & 0.102 \\
2004 & 70.31 & 6.79 & 0.097 \\
2005 & 55.31 & 5.56 & 0.101 \\
2006 & 45.08 & 4.34 & 0.096 \\
2007 & 79.45 & 7.92 & 0.100 \\
2008 & 51.77 & 5.25 & 0.101 \\
2009 & 40.39 & 3.45 & 0.085 \\
2010 & 28.39 & 0.81 & 0.029 \\
2011 & 59.41 & 5.71 & 0.096 \\
2012 & 39.41 & 3.65 & 0.093 \\
2013 & 81.09 & 8.14 & 0.100 \\
\hline & & & \\
& & & \\
\hline
\end{tabular}

"Fig. 3" illustrates the mean of selected Water Balance Parameters such as annual rainfall, surface runoff, evapotranspiration, field irrigation, total draft, consumptive use, soil moisture and recharge during 1986 to 2013. Groundwater recharge, surface runoff, evapotranspiration, consumptive use increases and decreases with precipitation and they show the same trends throughout the years. Field irrigation and total draft are almost proportional increasing trend throughout the years due to increasing demand of irrigation water. However, soil moisture shows a constant trend throughout the years. 


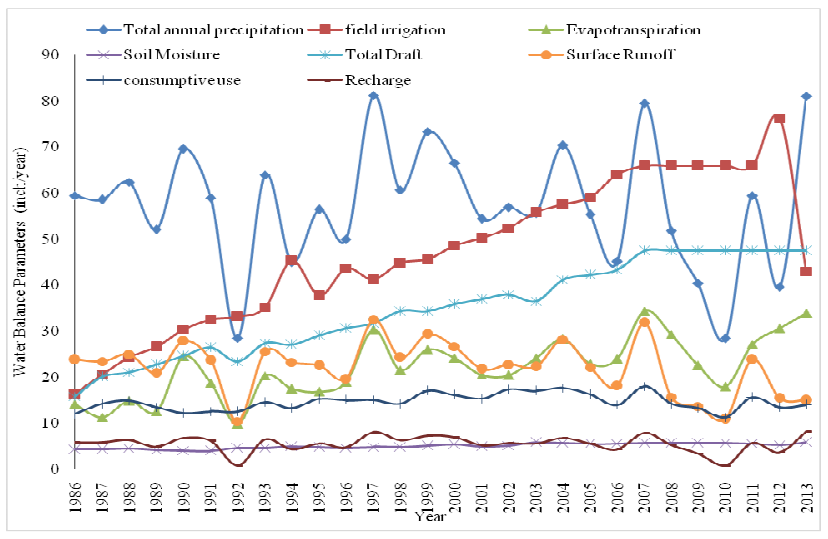

Figure 3. Total annual precipitation, field irrigation, evapotranspiration, soil moisture, total draft, consumptive use, surface runoff and recharge.

\subsection{Correlation and Regression Analysis}

Hydrological models are simplified, conceptual representations of a part of the hydrologic cycle. They are primarily used for hydrological prediction and for understanding hydrological processes. Models based on data using mathematical and statistical concepts to link a certain input (for instance rainfall) to the model output (for instance recharge). Commonly used techniques are regression, transfer functions, and system identification. The simplest of these models may be linear models, but it is common to deploy non-linear components to represent some general aspects of a catchment's response without going deeply into the real physical processes involved.

To determine groundwater recharge by Water Balance Method sufficient data are required. Due to lack of convenient data the method may gives large uncertainties for any study area. To overcome this difficulties and considering the phenomena of above discussion an attempt was taken to develop a relation between groundwater recharge and precipitation.

Non-linear least squares is the form of least squares analysis used to fit a set of $m$ observations with a model that is non-linear in $n$ unknown parameters $(m>n)$. It is used in some forms of non-linear regression.

The following empirical relationship was derived by best fitting the estimated values of rainfall recharge and the corresponding values of rainfall through the trial and error and the non-linear regression technique was shown in "Fig. 4".

$$
\mathrm{R}=0.85(\mathrm{P}-27.51)^{0.56}
$$

Where,

$$
\mathrm{R}=\text { Ground water recharge from rainfall (in); }
$$

$\mathrm{P}=$ Total annual rainfall (in).

The "proportion of variance" was found to be $99.73 \%$ for the above developed relationship. "Equation (2) indicates that recharge to ground water originates at $\mathrm{P}=27.51$ inch". Therefore, it gives almost no recharge for the year 1992 with $\mathrm{P}=28.50$ inch and 2010 with $\mathrm{P}=28.39$ inch. Table 2 presents the relative errors (\%) in the estimation of rainfall recharge from the developed empirical relationship as compared to water balance study and was found that the average percentage of error is 2.34. In almost all the years, the relative error was found to be less than $6 \%$. Therefore equation "(2)" can conveniently be used for better and quick assessment of ground water recharge in Godagari Upazila.

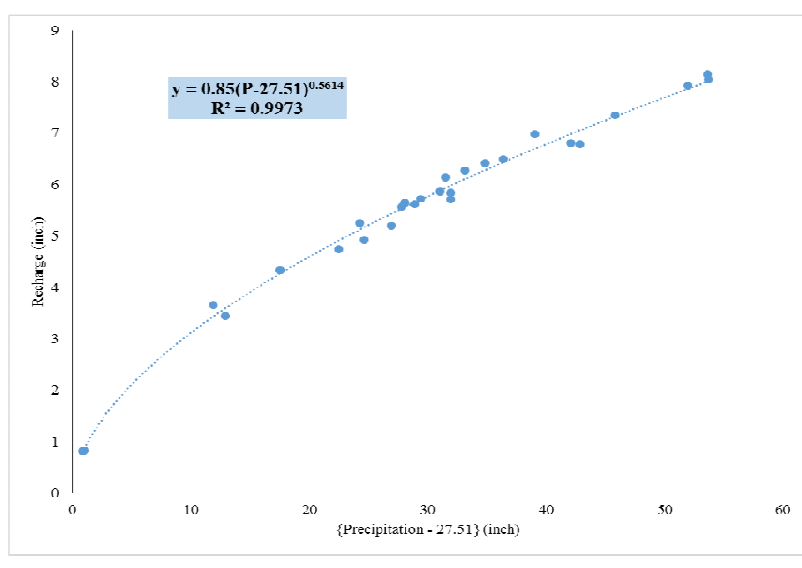

Figure 4. Rainfall recharge model for Godagari upazila.

\begin{tabular}{|c|c|c|c|c|}
\hline \multirow[b]{2}{*}{ Year } & \multirow[b]{2}{*}{$\begin{array}{c}\text { Total } \\
\text { Rainfall } \\
\text { P (in.) }\end{array}$} & \multicolumn{2}{|c|}{ Rainfall Recharge, $R$ (in) } & \multirow[b]{2}{*}{$\begin{array}{c}\text { Error } \\
(\%)\end{array}$} \\
\hline & & $\begin{array}{c}\text { Ground Water } \\
\text { Balance Study } \\
\text { (in.) }\end{array}$ & $\begin{array}{c}\text { Developed } \\
\text { Formula } \\
\mathrm{R}=\mathbf{0 . 8 5}(\mathrm{P}-27.51)^{0.56}\end{array}$ & \\
\hline 1986 & 59.45 & 5.84 & 5.98 & 2.45 \\
\hline 1987 & 58.54 & 5.87 & 5.89 & 0.36 \\
\hline 1988 & 62.36 & 6.41 & 6.28 & 2.00 \\
\hline 1989 & 52.17 & 4.92 & 5.18 & 5.21 \\
\hline 1990 & 69.57 & 6.81 & 6.98 & 2.43 \\
\hline 1991 & 58.98 & 6.15 & 5.93 & 3.48 \\
\hline 1992 & 28.50 & 0.83 & 0.86 & 2.55 \\
\hline 1993 & 63.90 & 6.49 & 6.44 & 0.90 \\
\hline 1994 & 44.96 & 4.33 & 4.26 & 1.50 \\
\hline 1995 & 56.38 & 5.62 & 5.65 & 0.66 \\
\hline 1996 & 49.96 & 4.74 & 4.91 & 3.61 \\
\hline 1997 & 81.18 & 8.04 & 8.00 & 0.52 \\
\hline 1998 & 60.63 & 6.28 & 6.11 & 2.70 \\
\hline 1999 & 73.31 & 7.34 & 7.32 & 0.31 \\
\hline 2000 & 66.54 & 6.98 & 6.69 & 4.16 \\
\hline 2001 & 54.41 & 5.21 & 5.43 & 4.40 \\
\hline 2002 & 56.89 & 5.73 & 5.71 & 0.30 \\
\hline 2003 & 55.59 & 5.65 & 5.57 & 1.47 \\
\hline 2004 & 70.31 & 6.79 & 7.05 & 3.85 \\
\hline 2005 & 55.31 & 5.56 & 5.54 & 0.51 \\
\hline 2006 & 45.08 & 4.34 & 4.28 & 1.35 \\
\hline 2007 & 79.45 & 7.92 & 7.86 & 0.87 \\
\hline 2008 & 51.77 & 5.25 & 5.13 & 2.30 \\
\hline 2009 & 40.39 & 3.45 & 3.60 & 4.29 \\
\hline 2010 & 28.39 & 0.81 & 0.80 & 1.16 \\
\hline 2011 & 59.41 & 5.71 & 5.98 & 4.64 \\
\hline 2012 & 39.41 & 3.65 & 3.44 & 5.70 \\
\hline \multirow[t]{2}{*}{2013} & 81.09 & 8.14 & 7.99 & 1.80 \\
\hline & & & \multicolumn{2}{|c|}{ Average Error $=2.33887$} \\
\hline
\end{tabular}

Table 2. Relative Errors with Developed Relationship.

\section{Conclusion}

The choice of method for estimating groundwater recharge should be conducted by the objectives of the study, 
available data and possibilities to get supplementary data. Water balance approach, basically a lumped model study, is a sustainable method of establishing the rainfall recharge coefficient and for evaluating the methods take on for the quantification of discharge and recharge from other sources.

Based on the water balance study for Godagari Upazila, a model has been recommended for the estimation of the groundwater recharge from rainfall with reasonable accuracy.

\section{References}

[1] C. P. Kumar, Estimation of natural groundwater recharge, ISH Journal of Hydraulic Engineering 3(1), 1977, 61-74.

[2] S. R. Saghravani, I. Yusoff, S. Mustapha and S. F. Saghravani, Estimating Groundwater Recharge Using Empirical Method: A Case Study in the Tropical Zone, Sains Malaysiana 42(5), $2013,553-560$

[3] H. Bouwer, Groundwater Hydrology (New York: McGrawhill Book Company 1978).

[4] S. Shukla, and F. H. Jaber, in Department of Agricultural and Biological Engineering (Ed.), Groundwater recharge from agricultural areas in the Flatwoods region of South Florida, 7 (Florida: University of Florida, 2006).

[5] S. S. Sumioka, and H.H. Bauer, Estimating groundwater recharge from precipitation on Whidbey and Camano Islands, Island County, Washington, water years 1998 and 1999, Water-Resources Investigations Report, 03-4101: Tacoma, WA: U.S. Geological Survey, 2003.

[6] C. Xi, Z. Zhang, X. Zhang, Y. Chen, M. Qian, and S. Peng, Estimation of groundwater recharge from precipitation and evapotranspiration by lysimeter measurement and soil moisture model, Journal of Hydrologic Engineering 13(50), 2008, 333-340.
[7] C. P. Kumar and P. V. Seethapathi, Assessment of natural groundwater recharge in upper Ganga canal command area, Journal of Applied Hydrology 15(4), 2002, 13-20.

[8] M. Anderson and W. Woessner, Applied Groundwater Modeling. San diego: Academic, 1992.

[9] M. A. Sophocleous, Combining the soil water balance and water-level fluctuation methods to estimate natural groundwater recharge: practical aspects. Journal of Hydrology 124, 1991, 229-241.

[10] S. Chandra, Groundwater studies project, Final report, School of hydrology, University of Roorkee publication, 1979.

[11] C. P. Kumar, Groundwater Assessment Methodology, National Institute of Hydrology, 2000, 21.

[12] Banglapedia: Godagari upazila, National Encyclopedia of Bangladesh, Internet website http://bpedia.org (last visit: 10-2-2014)

[13] A. A. Masum, M. Z. Alam and A. Chowdhury, Potential Rainwater Harvesting For Irrigation in Godagari Upazila, Rajshahi, International Journal of Engineering Research and Applications. ISSN: 2248-9622, 3(6), 2013, 173-175.

[14] H. M. Raghunath, Hydrology 1st ed., (H. S. Poplai for New Age International (P) Limited, 4835/24, Ansari Road, New Delhi-110002, 1997).

[15] P. J. R. Reddy, A Text book of Hydrology (Laxmi Pulicatians (PVT.) Ltd, 7/21, Ansari Rood, Daryagonj, New Delhi-110002, ISBN: 81-7008-066-5).

[16] S. K. Garg, Irrigation Engineering and Hydraulic Structures (Khanna publishers 2-B, Nath Market, Nai Sarak, Delhi-110006, 1976).

[17] B.D.R. Misstear, L. Brown, \& D. Daly, A methodology for making initial estimates of groundwater recharge from groundwater vulnerability mapping. Hydrogeology Journal 17(2), 2009, 275-285. 